\title{
Exudation of organic carbon by marine phytoplankton: dependence on taxon and cell size
}

\author{
Daffne C. López-Sandovall, ${ }^{1, *}$, Tamara Rodríguez-Ramos ${ }^{1}$, Pedro Cermeño ${ }^{1,2}$, \\ Emilio Marañón ${ }^{1}$ \\ ${ }^{1}$ Departamento de Ecología y Biología Animal, Universidad de Vigo, 36210 Vigo, Spain \\ ${ }^{2}$ Present address: Instituto de Ciencias del Mar, Consejo Superior de Investigaciones Cientificas, \\ Passeig Maritim de la Barceloneta 37-49, 08003 Barcelona, Spain
}

\begin{abstract}
We determined the relationship between photosynthetic production of dissolved organic carbon (OC) and phytoplankton cell size and taxonomic composition in cultures of marine phytoplankton at 3 different growth stages. We measured OC exudation in 22 species belonging to 5 phyla and spanning $>7$ orders of magnitude in cell volume. The extracellular release of OC in our cultures represented on average $\sim 2 \%$ of total carbon fixation, was not statistically different between growth stages, and was not correlated to cell size. The cell-specific OC exudation rate held an isometric relationship with cell size during the different growth phases (average slope: 0.95), which implies that general allometric models cannot be used to predict exudation in marine phytoplankton.
\end{abstract}

KEY WORDS: Phytoplankton · Exudation · Cell size $\cdot$ Taxonomic affiliation · Organic carbon

\section{INTRODUCTION}

The extracellular release in dissolved form of newly synthesized metabolites is a normal process (Mague et al. 1980) that takes place during all growth phases in phytoplankton (Hellebust 1965, Obernosterer \& Herndl 1995). The percentage of extracellular release (PER, the fraction of total primary production [PP] released in dissolved form) in natural phytoplankton assemblages ranges between 10 and $>35 \%$ of total PP (Anderson \& Zeutschel 1970, Teira et al. 2001b, Morán et al. 2002, Marañón et al. 2005, López-Sandoval et al. 2010), being more important in oligotrophic areas (Fogg 1983, Karl et al. 1998, Teira et al. 2001a, López-Sandoval et al. 2011). In phytoplankton cultures, PER values tend to be smaller, ranging from $<1$ to $20 \%$, with few species reaching values $>25 \%$, depending on the growth phase and culture conditions (Hellebust 1965, Mague et al.
1980, Malinsky-Rushansky \& Legrand 1996, Finkel 1998).

Exudation can be the result of 2 non-mutually exclusive processes: passive diffusion of small molecules $(<900 \mathrm{Da})$ through the cell membrane (Bjørnsen 1988), or a self-induced mechanism that occurs when phytoplankton organisms experience stressful conditions such as low nutrient concentration or high irradiance (Fogg 1983, Wood \& Van Valen 1990). Large molecules (>1500 Da) with low diffusion rate are frequently detected as part of the excreted material (Hellebust 1965, Lancelot 1984), suggesting that other mechanisms in addition to passive diffusion must be involved. Some phytoplankton species respond to a specific stimulus (e.g. exposure to certain wavelengths) by storing polymers in secretory vessels and then releasing them via autoregulated exocytosis (Chin et al. 2004, Orellana et al. 2011), but the mechanisms involved in exudation of other kinds of macromolecules still remain largely unknown. 
While there are several sources of labile dissolved organic carbon (OC) in the microbial plankton community (including cell leakage due to viral attack, sloppy feeding by zooplankton, breakage of faecal pellets, etc.) (Nagata 2000), in the present study we address only the production of dissolved OC that was fixed by photosynthesis and then released during a $2 \mathrm{~h}$ incubation period (Mague et al. 1980, Fogg 1983).

Some studies support the hypothesis that exudation should be more important in smaller cells, due to their high surface to volume quotient (Malinsky-Rushansky \& Legrand 1996, Teira et al. 2001a), but this view is not always shared (Finkel 1998, Marañón et al. 2004, López-Sandoval et al. 2010). The differences in the percentage of exudation among contrasting systems suggest a possible link between exudation and phytoplankton cell structure; however, it is difficult to test if cell size by itself has a direct effect on exudation, mainly because, in the field, other controlling variables tend to covary with phytoplankton cell size.

General allometric theory predicts that a metabolic rate $(M)$ is related to body size $(W)$ through the relationship: $M=W^{b}$, where $b$ is the size-scaling exponent, which usually takes a value of $3 / 4$ ('Kleiber's law'). Several models based on resource distribution networks have been proposed to explain why sizescaling relationships tend to have exponents that are multiples of 1/4 (West et al. 1997, 1999, Banavar et al. 2002, 2010). The validity of Kleiber's 3/4 power rule has been shown in animals (Savage et al. 2004), plants (Niklas \& Enquist 2001) and marine phytoplankton (Blasco et al. 1982, Finkel 2001, Finkel et al. 2004). A limitation of the latter studies is that they covered only a small number of phytoplankton species and a modest range in terms of cell size and taxonomic variability. Field studies and data meta-analyses have shown that this 'universal law' - which implies that the metabolic demand of an organism, per unit of mass, decreases as body size increases does not hold true in the case of phytoplankton (Tang \& Peters 1995, Marañón et al. 2007, Marañón 2008, Huete-Ortega et al. 2011). To our knowledge, there are no published studies of the size-scaling relationship of exudation in phytoplankton over a wide range of cell sizes and taxonomic affiliations.

Here we present data of exudation rates in 22 different species of phytoplankton in monospecific cultures, grown under the same controlled conditions and measured at 3 different growth phases with the same protocol. We provide data on the size scaling of dissolved OC production over a wide phylogenetic (5 phyla) and cell size ( 7 orders of magnitude in cell volume) range.

\section{MATERIALS AND METHODS}

\section{Phytoplankton cultures}

Species used for this study covered a cell size range from 0.12 to $2500000 \mu^{3}$ (Table 1). Cultures were obtained from Provasoli-Guillard National Center for Marine Algae (USA), Roscoff Culture Collection (France), Culture Collection of Algae and Protozoa (UK), Instituto Español de Oceanografía (Spain) and Estación de Ciencias Mariñas de Toralla (Spain). Cultures were grown in a 41 round-bottom flask on filtered $(0.2 \mu \mathrm{m})$, autoclaved and enriched seawater medium (details in Table 1), with silicate excluded in the case of non-diatoms and additional trace metals (L1 trace element solution) added in the case of dinoflagellates. The concentration of dissolved inorganic nitrogen was reduced 4 -fold, so that the N/P molar ratio was $\sim 6$ and nitrogen limitation was ensured. Culture flasks were set up in a culture chamber at a constant temperature $\left(18 \pm 0.5^{\circ} \mathrm{C}\right)$, with continuous aeration (except for dinoflagellates), and were exposed to a photon flux density of $\sim 250 \mu \mathrm{E} \mathrm{m} \mathrm{m}^{-2} \mathrm{~s}^{-1}$ and a 12:12 h light:dark cycle. Cells were kept in semi-continuous growth for 3 complete acclimation cycles in 11 aerated flasks before conducting measurements of exudation. An acclimation cycle was defined from the time when the inoculum was added to fresh medium to the time when the population reached the exponential phase and an aliquot was transferred to fresh medium again, thus starting a new cycle. Our cultures were not axenic. However, we regularly collected samples for bacterial abundance and found that the contribution of bacterial biomass to total OC was always $<0.4 \%$.

\section{Growth rates, cell density and cell size}

Growth was monitored daily by in vivo fluorescence measured with an Aquafluor Turner Design fluorometer, cell counts under the microscope and measurements of chl a concentration. Depending on the species' cell size, a Neubauer haemacytometer $\left(1 \mathrm{~mm}^{2}\right)$ or a $1 \mathrm{ml}$ Sedwick-Rafter chamber were used to determine cell abundance. For Coscinodiscus radiatus and $C$. wailesii, cells were counted by sedimenting 5 or $10 \mathrm{ml}$ aliquots for $24 \mathrm{~h}$ in Utermöhl chambers. Enough cells were counted to keep the coefficient of variation of the mean population abundance estimate $<20 \%$. The abundances of Synechococcus sp., Prochlorococcus sp., Micromonas pusilla and Ostreococcus tauri were determined by flow 
Table 1. List of phytoplankton species studied

\begin{tabular}{|c|c|c|c|c|c|}
\hline Phylum & Class & Species & Clone/origin & $\begin{array}{l}\text { Size } \\
\left(\mu m^{3}\right)\end{array}$ & $\begin{array}{l}\text { Culture medium, } \\
\qquad \mathrm{NO}^{3-} / \mathrm{NH}^{4+}\end{array}$ \\
\hline Ochrophyta & Bacillariophyceae & $\begin{array}{l}\text { Skeletonema costatum } \\
\text { Thalassiosira rotula } \\
\text { Phaeodactylum tricornutum } \\
\text { Thalassiosira weissflogii } \\
\text { Melosira nummoloides } \\
\text { Coscinodiscus radiatus } \\
\text { Coscinodiscus wailesii } \\
\text { Ditylum brightwellii }\end{array}$ & $\begin{array}{l}\text { CCAP 1077/1C } \\
\text { CCAP 1085/20 } \\
\text { ECIMAT } \\
\text { CCMP } 1336 \\
\text { ECIMAT } \\
\text { CCMP } 312 \\
\text { CCMP } 2513 \\
\text { CCMP } 361\end{array}$ & $\begin{array}{r}242 \\
2597 \\
93 \\
1163 \\
2285 \\
81955 \\
2498458 \\
75827\end{array}$ & $\begin{array}{l}\mathrm{f} / 4, \mathrm{f} / 16^{\mathrm{a}} \\
\mathrm{f} / 8, \mathrm{f} / 32^{\mathrm{a}} \\
\mathrm{f} / 4, \mathrm{f} / 16^{\mathrm{a}} \\
\mathrm{f} / 4, \mathrm{f} / 16^{\mathrm{a}} \\
\mathrm{f} / 4, \mathrm{f} / 16^{\mathrm{a}} \\
\mathrm{f} / 4, \mathrm{f} / 16^{\mathrm{a}} \\
\mathrm{f} / 4, \mathrm{f} / 16^{\mathrm{a}} \\
\mathrm{f} / 4, \mathrm{f} / 16^{\mathrm{a}}\end{array}$ \\
\hline Myzozoa & Peridinea & $\begin{array}{l}\text { Protoceratium reticulatum } \\
\text { Akashiwo sanguinea } \\
\text { Alexandrium minutum } \\
\text { Alexandrium tamarense }\end{array}$ & $\begin{array}{l}\text { IEO-Vigo } \\
\text { IEO -Vigo } \\
\text { CCMP } 113 \\
\text { EF04 }\end{array}$ & $\begin{array}{r}23823 \\
47349 \\
5575 \\
88836\end{array}$ & $\begin{array}{l}\mathrm{L} / 2, \mathrm{~L} / 8^{\mathrm{b}} \\
\mathrm{L} / 2, \mathrm{~L} / 8^{\mathrm{b}} \\
\mathrm{L} / 2, \mathrm{~L} / 8^{\mathrm{b}} \\
\mathrm{L} / 2, \mathrm{~L} / 8^{\mathrm{b}}\end{array}$ \\
\hline Haptophyta & Pavlovophyceae & $\begin{array}{l}\text { Emiliania huxleyi } \\
\text { Gephyrocapsa oceanica } \\
\text { Calcidiscus leptoporus } \\
\text { Isochrysis galbana } \\
\text { Pavlova lutheri }\end{array}$ & $\begin{array}{l}\text { CCMP } 371 \\
\text { CCMP } 2051 \\
\text { RCC1169 } \\
\text { ECIMAT } \\
\text { CCMP } 1325\end{array}$ & $\begin{array}{r}158 \\
82 \\
51 \\
64 \\
45\end{array}$ & $\begin{array}{l}\mathrm{f} / 4, \mathrm{f} / 16^{\mathrm{a}} \\
\mathrm{f} / 4, \mathrm{f} / 16^{\mathrm{a}} \\
\mathrm{f} / 4, \mathrm{f} / 16^{\mathrm{a}} \\
\mathrm{f} / 8, \mathrm{f} / 32^{\mathrm{a}} \\
\mathrm{f} / 4, \mathrm{f} / 16^{\mathrm{a}}\end{array}$ \\
\hline Ochrophyta & Eustigmatophyceae & Nannochloropsis gaditana & ECIMAT & 8.6 & $\mathrm{f} / 4, \mathrm{f} / 16^{\mathrm{a}}$ \\
\hline Chlorophyta & Mamiellophyceae & $\begin{array}{l}\text { Micromonas pusilla } \\
\text { Ostreococcus tauri }\end{array}$ & $\begin{array}{l}\text { RCC } 496 \\
\text { RCC } 116\end{array}$ & $\begin{array}{r}10.7 \\
2.4\end{array}$ & $\begin{array}{l}\mathrm{K} / 2, \mathrm{~K} / 8^{\mathrm{c}} \\
\mathrm{K} / 2, \mathrm{~K} / 8^{\mathrm{c}}\end{array}$ \\
\hline Cyanophyta & Cyanophyceae & $\begin{array}{l}\text { Synechococcus sp. } \\
\text { Prochlorococcus sp. }\end{array}$ & $\begin{array}{l}\text { RCC } 33 \\
\text { RCC } 267\end{array}$ & $\begin{array}{l}0.41 \\
0.12\end{array}$ & $\begin{array}{c}\mathrm{f} / 4, \mathrm{f} / 16^{\mathrm{a}} \\
\text { PCR-S11, PCR-S11/4 }\end{array}$ \\
\hline
\end{tabular}

cytometry in $2.5 \mathrm{ml}$ samples, fixed with $0.250 \mu \mathrm{l}$ paraformaldehyde ( $1 \%$ final concentration) and glutaraldehyde $(0.05 \%$ final concentration), using a FACScan flow cytometer (Becton Dickinson). Chl a concentration was measured fluorometrically on a TD-700 fluorometer after filtration of duplicate $5 \mathrm{ml}$ samples on GF/F filters, freezing of the filters at $-20^{\circ} \mathrm{C}$ and extraction with $90 \%$ acetone. Biovolume was measured with a Leica DLMB microscope using the NIS-Elements BR 3.0 image analysis software. Critical cell dimensions were obtained in at least 100 cells by assigning different geometric shapes that were most similar to the real shape of each phytoplankton species Sun \& Liu (2003).

\section{Particulate organic carbon determination}

Duplicate, $10 \mathrm{ml}$ aliquots of culture were filtered onto pre-combusted $\left(450^{\circ} \mathrm{C}\right.$ for $\left.8 \mathrm{~h}\right) \mathrm{GF} / \mathrm{F}$ filters, which were then stored at $-20^{\circ} \mathrm{C}$. Before analysis, filters were placed in a desiccator for $48 \mathrm{~h}$ at room temperature. Samples were analysed with a Carlo Erba Instruments EA1108 elemental analyser using an acetanilide standard as reference. In the case of coccolithophorids, 2 extra samples were taken and acid- ified with $\mathrm{HCl}$ fumes prior to analysis, to remove the carbon present as calcium carbonate. The elemental analysis procedure measures all carbon present in the sample, both organic and inorganic (e.g. $\mathrm{CaCO}_{3}$ ). Hence, OC in coccolithophores was determined from the difference between the carbon measured in nonacidified (all carbon is measured) and acidified (only $\mathrm{OC}$ is measured) samples. Carbon biomass of each species was calculated by dividing the concentration of particulate $\mathrm{OC}$ by cell abundance.

\section{Dissolved and particulate primary production}

Sampling was conducted during the exponential growth phase, an intermediate stage and during the stationary phase. Exudation rates were measured as described in detail by Marañón et al. (2004). For each phase, $100 \mathrm{ml}$ aliquots from each culture were taken and placed in an acid-washed Pyrex glass bottle; 5 subsamples were taken: 3 light and 2 glass vials $(20 \mathrm{ml})$ were filled with the sample, spiked with $1 \mu \mathrm{Ci}(37 \mathrm{KBq})$ of $\mathrm{NaH}^{14} \mathrm{CO}_{3}$, and incubated for $2 \mathrm{~h}$. At the end of the incubation period, 2 aliquots of $5 \mathrm{ml}$ from each incubation bottle were filtered through $0.2 \mu \mathrm{m}$ polycarbonate filters $(25 \mathrm{~mm}$ in dia- 
meter) using low vacuum pressure $(<50 \mathrm{~mm} \mathrm{Hg})$. After being acidified to a $\mathrm{pH}$ of $\sim 2$ with $100 \mu \mathrm{l}$ of

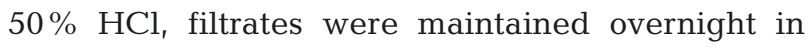
open scintillation vials $(20 \mathrm{ml})$ placed on an orbital shaker. After inorganic ${ }^{14} \mathrm{C}$ removal, $15 \mathrm{ml}$ of high sample capacity scintillation cocktail was added to each filtrate. Filtrates were stored in the dark until counting. The inorganic ${ }^{14} \mathrm{C}$ present in the filters was removed by exposing them to concentrated $\mathrm{HCl}$ fumes for $12 \mathrm{~h}$. The filters were then placed in $5 \mathrm{ml}$ scintillation vials to which $4 \mathrm{ml}$ of scintillation cocktail were added. The radioactivity of each sample was determined using a Tri-Carb 3100TR scintillation counter. To calculate the rates of dissolved and particulate carbon production, the black bottle DPMs (disintegrations per minute) were subtracted from the light bottle DPMs for correction of any non-photosynthetic ${ }^{14} \mathrm{C}$ incorporation; possible errors were due to organic contamination of ${ }^{14} \mathrm{C}$ stocks, or incomplete removal of inorganic ${ }^{14} \mathrm{C}$ from the filtrates. As shown by Markager (1998), most of the ${ }^{14} \mathrm{C}$-signal in black bottle samples during short $(<3 \mathrm{~h})$ incubations arises from incomplete removal of inorganic ${ }^{14} \mathrm{C}$ during acidification as well as ${ }^{14} \mathrm{C}$ adsorption onto particles. Previous experiments using the same protocol indicated that Time 0 samples have similar DPM counts to those obtained from dark bottle incubations (Marañón et al. 2004), which indicates that the ${ }^{14} \mathrm{C}$ signal in dark bottle samples does not represent a biological process of $\mathrm{CO}_{2}$ fixation. Thus, failing to subtract the black bottle DPM counts may result in severe overestimation of the real rates of $\mathrm{PP}$, as concluded also by Banse (1993). The DPM count in the filtrates from the light bottle was always in the order of several hundreds, and the light to dark bottle DPM count ratio was always $>2$. We used a constant value of $25700 \mathrm{mg}$ $\mathrm{C} \mathrm{m}^{-3}$ for the concentration of dissolved inorganic carbon. To the extent that different species had different growth rates, it is conceivable that equilibration of the labelled carbon inside the cells may have proceeded at different paces in different cultures. However, both small (e.g. $<10 \mu^{3}$ in cell volume) and large $\left(>10000 \mu^{3}\right)$ species had similar growth rates, which means that the overall size-scaling slope for the rates of dissolved and particulate PP should not have been affected by differences in the time required for isotopic equilibration.

\section{RESULTS}

The percentage of extracellular release was on average $\sim 2 \%$ of total carbon fixation (Table 2), ranged from 0.3 to $10 \%$ (among species and growth phases) and was not correlated to cell size (Fig. 1). The carbon-specific exudation rate, which took a mean value of $0.001 \mathrm{~h}^{-1}( \pm 0.001 \mathrm{SD})$, and the percentage of extracellular release did not show significant differences among growth phases (KruskalWallis $H$-test: $\mathrm{p}=0.91$ and $\mathrm{p}=0.51$, respectively).

To assess how the percentage of extracellular release varied with cell size and among species, all data were grouped in different size classes $(<2,2$ to 20 and $>20 \mu \mathrm{m}$ in equivalent spherical diameter), and also according to taxonomic affiliation (diatoms, dinoflagellates, coccolithophorids, cyanobacteria and others). The lowest percentage of exudation was

Table 2. Percentage of extracellular release (PER) of dissolved organic carbon measured for each phytoplankton species during the 3 growth phases. Further taxonomic details, see Table 1

\begin{tabular}{|c|c|c|c|c|c|c|}
\hline \multirow[t]{2}{*}{ Species } & \multirow[t]{2}{*}{$\mathrm{N}$} & \multicolumn{3}{|c|}{$-\operatorname{PER}(\%)-$} & \multicolumn{2}{|c|}{$95 \%$ conf. int. } \\
\hline & & Mean & $\mathrm{SD}$ & Median & Lower & Upper \\
\hline S. costatum & 3 & 0.30 & 0.17 & 0.30 & -0.13 & 0.72 \\
\hline$T$. rotula & 3 & 0.39 & 0.11 & 0.39 & 0.10 & 0.67 \\
\hline P. tricornutum & 3 & 0.31 & 0.03 & 0.32 & 0.23 & 0.38 \\
\hline T. weissflogii & 3 & 0.91 & 0.90 & 0.52 & -1.32 & 3.13 \\
\hline M. nunmuloides ${ }^{\mathrm{a}}$ & 1 & 1.25 & & & & \\
\hline C. radiatus & 3 & 1.30 & 0.19 & 1.22 & 0.82 & 1.77 \\
\hline C. wailesii & 3 & 3.53 & 1.68 & 3.38 & -0.65 & 7.71 \\
\hline D. brightwelii & 3 & 2.26 & 0.82 & 2.13 & 0.21 & 4.30 \\
\hline P. reticulatum & 3 & 1.68 & 1.07 & 1.08 & -0.98 & 4.34 \\
\hline A. sanguinea & 3 & 10.37 & 2.62 & 10.36 & 3.86 & 16.88 \\
\hline A. minutum & 3 & 4.23 & 2.70 & 3.54 & -2.48 & 10.95 \\
\hline A. tamarense & 3 & 3.13 & 2.32 & 3.54 & -2.62 & 8.88 \\
\hline E. huxleyi & 3 & 0.41 & 0.12 & 0.47 & 0.12 & 0.70 \\
\hline G. oceanica & 3 & 1.83 & 0.66 & 1.75 & 0.19 & 3.47 \\
\hline C. leptoporus & 3 & 0.95 & 0.47 & 0.83 & -0.21 & 2.12 \\
\hline I. galbana & 3 & 0.92 & 0.78 & 0.63 & -1.03 & 2.87 \\
\hline P. lutheri & 3 & 1.03 & 0.33 & 0.89 & 0.21 & 1.86 \\
\hline N. gaditana & 3 & 1.14 & 0.27 & 1.16 & 0.46 & 1.82 \\
\hline M. pusilla & 3 & 9.14 & 1.67 & 8.39 & 4.99 & 13.28 \\
\hline O. tauri & 3 & 1.69 & 0.87 & 1.84 & -0.46 & 3.84 \\
\hline Synechococcus sp. & 3 & 1.41 & 0.61 & 1.39 & -0.11 & 2.93 \\
\hline Prochlorococcus sp. & 3 & 1.92 & 0.76 & 1.78 & 0.03 & 3.80 \\
\hline All data & 64 & 2.31 & 2.81 & 1.32 & 1.61 & 3.01 \\
\hline
\end{tabular}


observed in nanophytoplankton (PER $<2 \%$ in the 3 growth phases) and also in coccolithophorids, during exponential and intermediate phases (mean PER = 0.8 and $0.9 \%$, respectively) (Fig. 2); the highest percentages were calculated for micro- and picophytoplankton $(<2.0 \mu \mathrm{m})$ (Fig. 2).

Although the percentage of exudation varied markedly among phylogenetic groups and size classes, the differences were not significant (Kruskal-Wallis $H$-test: $\mathrm{p}>0.05$ for each growth phase in both cases). The higher percentages of exudation within the dinoflagellates (average PER $>4 \%$ ) and the $>20 \mu \mathrm{m}$ size class (average PER $>2 \%$ ) (Fig. 2) was due to the high values of Akashiwo sanguinea (mean PER = $10.4 \%$ ), whereas those found in the $<2.0 \mu \mathrm{m}$ size class were due to the flagellate Micromonas pusilla (mean PER $=9.1 \%$ ) (Table 2, Fig. 2). Even though there were no significant differences in PER among phylogenetic groups, highly significant differences existed between species (Kruskal-Wallis $H$-test: $\mathrm{p}<$ 0.001).
Both cell volume and cell biomass were very good predictors of the cell-specific exudation rate (Table 3, Fig. 3). The slope of the log-log relationship between the exudation rate and cell volume $(b=0.95)$ and cell biomass $(b=1.08)$ was significantly higher than 0.75 in both cases ( $t$-test: p < 0.01 ) and not significantly different from 1.0 (t-test: p > 0.05) (Table 3, Fig. 3); this pattern remained during the 3 different growth phases (Table 3). Hence, our results indicate that $\mathrm{OC}$ exudation does not scale allometrically either with cell biovolume or cell biomass, but scales isometrically. Cell carbon scaled with cell biovolume with an exponent of 0.88 (i.e. $C \propto V^{0.88}$; data not shown), and, given that exudation rate scaled with $V$ with an exponent of 0.95 $\left(M \propto V^{0.95}\right)$, the relationship between exudation rate and biomass presented an even higher exponent. The $95 \%$ confidence intervals revealed no significant differences in the size-scaling exponent of exudation rate between growth phases (Table 3), which highlights the robustness of these patterns.

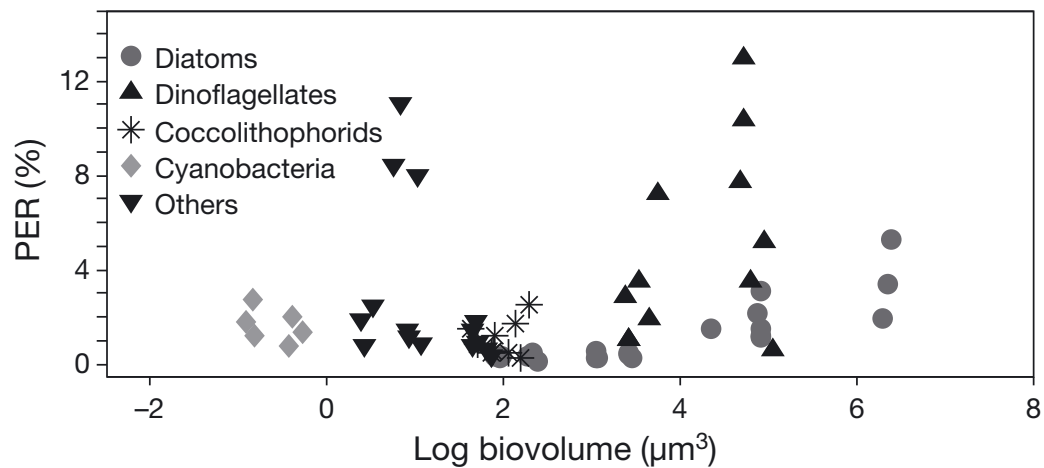

Fig. 1. Relationships between the percentage of extracellular release (PER) and cell size measured as cell biovolume $\left(\mu^{3}\right)$ for 3 different growth phases (exponential, intermediate and stationary)

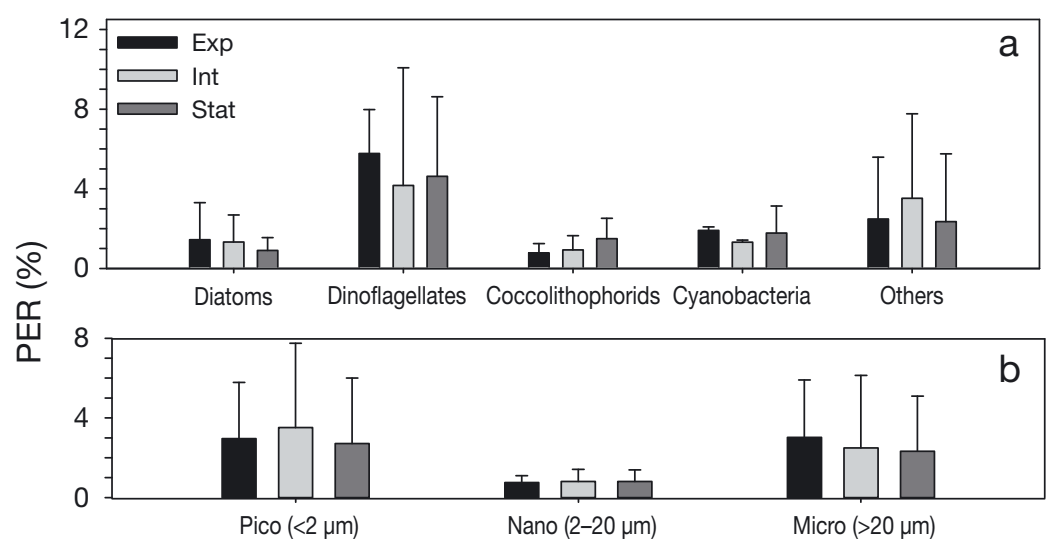

Fig. 2. Mean $( \pm \mathrm{SD}$ ) percentage of extracellular release (PER) of (a) different phytoplankton groups and (b) different size classes measured throughout 3 growth phases (exponential [Exp], intermediate [Int] and stationary [Stat])

\section{DISCUSSION}

When microalgae experience uncoupling between carbon fixation and growth rate (due to nutrient deficiency), strategies such as exudation of dissolved organic compounds might help cells to cope with the 'excess carbon' obtained during photosynthesis (Wood \& Van Valen 1990, BermanFrank \& Dubinsky 1999). Previous studies on exudation in phytoplankton cultures suggesed that as growth rates decline (at the stationary stage, when nutrients become limiting), exudation of dissolved OC increases (Myklestad 1977, Zlotnik \& Dubinsky 1989, Obernosterer \& Herndl 1995). However, in these studies only a small number of phytoplankton species were analysed, and only a few of them included $>1$ measurement during the phytoplankton growth cycle. In this study we obtained data from 3 different growth phases and 22 phytoplankton species, providing evidence that exudation remains constant between growth phases.

All data for the stationary phase were obtained when nitrate concen- 
Table 3. Percentage of extracellular release (PER; mean \pm $\mathrm{SD})$ and parameters of the size-scaling relationships for exudation rate at 3 growth phases. Reduced major axis regression was used to determine the relationship between log cell volume $\left(\mu^{3} \mathrm{cell}^{-1}\right)$ or cell biomass $\left(\mathrm{pgC} \mathrm{cell}^{-1}\right)$ (independent variables) and $\log$ exudation rate $\left(\mathrm{pgC} \mathrm{cell}^{-1} \mathrm{~h}^{-1}\right)$ (dependent variable). Bootstrap confidence limits (95\%) for the intercept and slope in parentheses. p-values refer to the comparison between the size-scaling slope of the exudation rate with expected values of 1.0 ; at an expected slope of 0.75 , $\mathrm{p}<0.001$ in all cases

\begin{tabular}{|c|c|c|}
\hline Growth phase & $\begin{array}{l}\text { Volume } \\
\left(\mu \mathrm{m}^{3}\right)\end{array}$ & $\begin{array}{l}\text { Biomass } \\
(\mathrm{pgC})\end{array}$ \\
\hline \multicolumn{3}{|c|}{$\begin{array}{l}\text { Exponential } \\
(\mathrm{PER}=2.5 \pm 2.6 \% ; \mathrm{n}=21)\end{array}$} \\
\hline Intercept & $-3.9(-4.3,-3.4)$ & $-3.2(-3.4,-2.9)$ \\
\hline Slope & $0.94(0.8,1.1)$ & $1.06(0.9,1.1)$ \\
\hline $\mathrm{r}^{2}$ & 0.90 & 0.95 \\
\hline $\mathrm{p}$ & 0.36 & 0.24 \\
\hline \multicolumn{3}{|c|}{$\begin{array}{l}\text { Intermediate } \\
(\mathrm{PER}=2.3 \pm 3.4 \% ; \mathrm{n}=21)\end{array}$} \\
\hline Intercept & $-4.0(-4.4,-3.7)$ & $-3.3(-3.5,-3.1)$ \\
\hline Slope & $0.92(0.8,1.0)$ & $1.04(0.9,1.1)$ \\
\hline $\mathrm{r}^{2}$ & 0.94 & 0.96 \\
\hline $\mathrm{P}$ & 0.13 & 0.39 \\
\hline \multicolumn{3}{|c|}{$\begin{array}{l}\text { Stationary } \\
(\mathrm{PER}=2.1 \pm 2.6 \% ; \mathrm{n}=22)\end{array}$} \\
\hline Intercept & $-4.4(-4.8,-4.0)$ & $-3.6(-3.9,-3.3)$ \\
\hline Slope & $1.0(0.9,1.1)$ & $1.13(1.0,1.2)$ \\
\hline$r^{2}$ & 0.93 & 0.95 \\
\hline $\mathrm{P}$ & 0.90 & 0.03 \\
\hline \multicolumn{3}{|c|}{$\begin{array}{l}\text { All data } \\
(\mathrm{PER}=2.3 \pm 2.8 \% ; \mathrm{n}=64)\end{array}$} \\
\hline Intercept & $-4.1(-4.3,-3.9)$ & $-3.4(-3.5,-3.2)$ \\
\hline Slope & $0.96(0.9,1.0)$ & $1.08(1.0,1.1)$ \\
\hline$r^{2}$ & 0.91 & 0.95 \\
\hline $\mathrm{P}$ & 0.20 & 0.01 \\
\hline
\end{tabular}

tration in the bulk medium was near or below the detection limit and the carbon-specific carbon fixation rate had the lowest values. However, it is possible that the cells' ability to store nitrogen intracellularly may prevent a strong nutrient deficiency, which tends to be associated with high PER values (Obernosterer \& Herndl 1995).

Differences in exudation among species (Hellebust 1965, Beardall \& Raven 2001) might be important even within one single class (diatoms) (Finkel 1998, Beardall \& Raven 2001). Our results agree with previous reports indicating that not only the quality but also the quantity of dissolved organic matter exuded by algae may change depending on the species (Wolter 1982, Romera-Castillo et al. 2010). However, at the same time, the percentage of exudation for a given species will vary according to the conditions that the population has previously experienced (Bertilsson et al. 2005, Borchard \& Engel 2012).

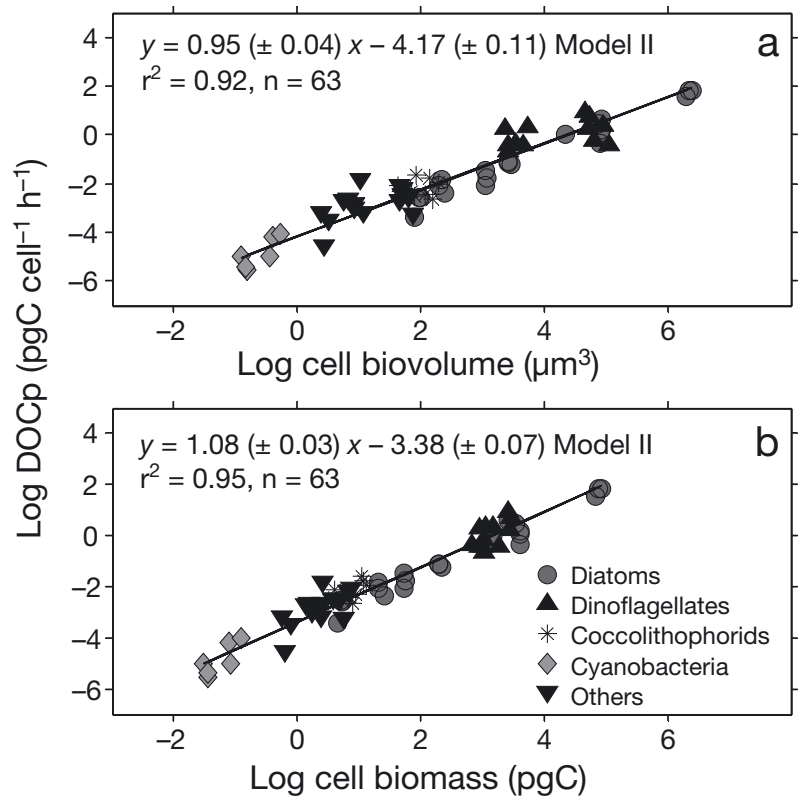

Fig. 3. Relationship between log cell-specific exudation rates (DOCp) and log cell size measured as (a) biovolume $\left(\mu \mathrm{m}^{3}\right)$ and (b) biomass (pg C cell ${ }^{-1}$ ) for different phytoplankton groups throughout the 3 growth phases

The larger surface to volume quotient and the intrinsically thinner diffusion boundary layer which facilitates nutrient uptake in smaller cells (Chisholm 1992, Raven 1998) could also favour a higher diffusion (exudation) of low-molecular weight compounds through the cell membrane. Malinsky-Rushansky \& Legrand (1996), using cultures of 3 different phytoplankton species (Navicula filata, Pavlova lutheri and a Chlorella-like picoeukaryote), with a size range from 1.5 to $8 \mu \mathrm{m}$ in diameter, showed that the percentage of exudation was higher in the picoeukaryote-like cells $(12.6 \%)$. In contrast, our results obtained from a much wider range in size $(0.1$ to $10^{6} \mathrm{\mu m}^{3}$ in cell volume) demonstrate that the percentage of exudation has no relationship with cell size. This counterintuitive result indicates that exudation of recently synthesised metabolites, as measured with the ${ }^{14} \mathrm{C}$-uptake technique over short time scales, depends on the rate of total carbon fixation and not on diffusion processes. As we discuss below, the rate of mass-specific photosynthetic carbon fixation, as well as other metabolic rates, seem to be largely independent of cell size in phytoplankton.

Recently, the applicability of Kleiber's $3 / 4$ power rule has been assessed for unicellular organisms (Johnson et al. 2009, DeLong et al. 2010, Finkel et al. 2010) and specifically for phytoplankton (Marañón et al. 2007, Marañón 2008, Huete-Ortega et al. 2011). 
These studies all suggest a departure from the $3 / 4$ power relationships toward isometry in the metabolic rate of photosynthetic unicells. Here we provide robust data indicating that this departure also holds true for a metabolic loss process such as exudation, which scales isometrically with cell size. Thus, on a biomass- or biovolume-specific basis, the relative importance of dissolved PP is largely size-independent in marine phytoplankton.

Acknowledgements. We thank M. P. Lorenzo and A. Fernández for their help with laboratory work, J. M. Blanco and J. Rodríguez for the flow cytometry data and S. Fraga for providing some phytoplankton cultures. This research was funded by the Spanish Ministerio de Educación y Ciencia through the research project 'Macroecological patterns in marine phytoplankton' (Grant CTM2008-03699/MAR to E.M.). D.C.L.S. was supported by postgraduate fellowships from the Mexican Council of Science and Technology (CONACyt) and the Xunta de Galicia (Spain).

\section{LITERATURE CITED}

Anderson GC, Zeutschel RP (1970) Release of dissolved organic matter by marine phytoplankton in coastal and offshore areas of the Northeast Pacific Ocean. Limnol Oceanogr 15:402-407

Banavar JR, Damuth J, Maritan A, Rinaldo A (2002) Supplydemand balance and metabolic scaling. Proc Natl Acad Sci USA 99:10506-10509

Banavar JR, Moses ME, Brown JH, Damuth J, Rinaldo A, Sibly RM, Maritan A (2010) A general basis for quarterpower scaling in animals. Proc Natl Acad Sci USA 107: 15816-15820

Banse K (1993) On the dark bottle in the ${ }^{14} \mathrm{C}$ method for measuring marine phytoplankton production. ICES Mar Sci Symp 197:132-140

Beardall J, Raven JA (2001) Algal metabolism. John Wiley \& Sons, London

Berman-Frank I, Dubinsky Z (1999) Balanced growth in aquatic plants: myth or reality? Phytoplankton use the imbalance between carbon assimilation and biomass production to their strategic advantage. Bioscience 49: 29-37

Bertilsson S, Berglund O, Pullin MJ, Chisholm SW (2005) Release of dissolved organic matter by Prochlorococcus. Vie Milieu 55:225-231

Bjørnsen PK (1988) Phytoplankton exudation of organic matter: why do healthy cells do it? Limnol Oceanogr 33: 151-154

Blasco D, Packard TT, Garfield PC (1982) Size dependence of growth rate, respiratory electron transport system activity and chemical composition in marine diatoms in the laboratory. J Phycol 18:58-63

Borchard C, Engel A (2012) Organic matter exudation by Emiliania huxleyi under simulated future ocean conditions. Biogeosci Discuss 9:1199-1236

Chin WC, Orellana MV, Quesada I, Verdugo P (2004) Secretion in unicellular marine phytoplankton: demonstration of regulated exocytosis in Phaeocystis globosa. Plant Cell Physiol 45:535-542
Chisholm SW (1992) Phytoplankton size. In: Falkowski PG, Woodhead AD (eds) Primary productivity and biogeochemical cycles in the sea. Plenum, New York, NY

> DeLong JP, Okie JG, Moses ME, Sibly RM, Brown JH (2010) Shifts in metabolic scaling, production, and efficiency across major evolutionary transitions of life. Proc Natl Acad Sci USA 107:12941-12945

Finkel ZV (1998) Diatoms: size and metabolic processes. MS thesis, Dalhousie University, Halifax, NS

> Finkel ZV (2001) Light absorption and size scaling of lightlimited metabolism in marine diatoms. Limnol Oceanogr 46:86-94

> Finkel ZV, Irwin AJ, Schofield O (2004) Resource limitation alters the $3 / 4$ size scaling of metabolic rates in phytoplankton. Mar Ecol Prog Ser 273:269-279

Finkel ZV, Beardall J, Flynn KJ, Quigg A, Rees TAV, Raven JA (2010) Phytoplankton in a changing world: cell size and elemental stoichiometry. J Plankton Res 32: 119-137

Fogg GE (1983) The ecological significance of extracellular products of phytoplankton photosynthesis. Bot Mar 26: 3-14

Guillard RRL (1975) Culture of phytoplankton for feeding marine invertebrates. In: Smith WL, Chanley MH (ed) Culture of marine invertebrate animals. Plenum, New York, NY

> Guillard R, Hargraves P (1993) Stichochrysis immobilis is a diatom, not a chrysophyte. Phycologia 32:234-236

Hellebust JA (1965) Excretion of some organic compounds by marine phytoplankton. Limnol Oceanogr 10:192-206

Huete-Ortega M, Cermeño P, Calvo-Díaz A, Marañon E (2011) Isometric size-scaling of metabolic rate and the size abundance distribution of phytoplankton. Proc R Soc Lond B Biol Sci 279:1815-1823

Johnson MD, Völker J, Moeller HV, Laws E, Breslauer KJ, Falkowski PG (2009) Universal constant for heat production in protists. Proc Natl Acad Sci USA 106:6696-6699

> Karl DM, Hebel DV, Bjorkman K, Letelier RM (1998) The role of dissolved organic matter release in the productivity of the oligotrophic North Pacific Ocean. Limnol Oceanogr 43:1270-1286

Keller M, Guillard R (1985) Factors significant to marine dinoflagellate culture. In: Anderson DM, White AW, Baden DG (eds) Toxic dinoflagellates. Elsevier, New York, NY, p 113-116

> Lancelot C (1984) Extracellular release of small and large molecules by phytoplankton in the southern bight of the North Sea. Estuar Coast Shelf Sci 18:65-77

López-Sandoval DC, Marañón E, Fernández A, González J and others (2010) Particulate and dissolved primary production by contrasting phytoplankton assemblages during mesocosm experiments in the Ria de Vigo (NW Spain). J Plankton Res 32:1231-1240

> López-Sandoval DC, Fernández A, Marañón E (2011) Dissolved and particulate primary production along a longitudinal gradient in the Mediterranean Sea. Biogeosciences 8:815-825

$>$ Mague TH, Friberg E, Hughes DJ, Morris I (1980) Extracellular release of carbon by marine phytoplankton; a physiological approach. Limnol Oceanogr 25:262-279

> Malinsky-Rushansky NZ, Legrand C (1996) Excretion of dissolved organic carbon by phytoplankton of different sizes and subsequent bacterial uptake. Mar Ecol Prog Ser 132:249-255

> Marañón E (2008) Inter-specific scaling of phytoplankton 
production and cell size in the field. J Plankton Res 30: $157-163$

Marañón E, Cermeño P, Fernández E, Rodríguez J, Zabala L (2004) Significance and mechanisms of photosynthetic production of dissolved organic carbon in a coastal eutrophic ecosystem. Limnol Oceanogr 49:1652-1666

> Marañón E, Cermeño P, Pérez V (2005) Continuity in the photosynthetic production of dissolved organic carbon from eutrophic to oligotrophic waters. Mar Ecol Prog Ser 299:7-17

Marañón E, Cermeño P, Rodriguez J, Zubkov MV, Harris RP (2007) Scaling of phytoplankton photosynthesis and cell size in the ocean. Limnol Oceanogr 52:2190-2198

Markager S (1998) Dark uptake of inorganic ${ }^{14} \mathrm{C}$ in oligotrophic oceanic waters. J Plankton Res 20:1813-1836

Morán XAG, Estrada M, Gasol JM, Pedrós-Alió C (2002) Dissolved primary production and the strength of phytoplankton-bacterioplankton coupling in contrasting marine regions. Microb Ecol 44:217-223

Myklestad S (1977) Production of carbohydrates by marine planktonic diatoms. II. Influence of the ratio in the growth medium on the assimilation ratio, growth rate, and production of cellular and extracellular carbohydrates by Chaetoceros affinis var. willei (Gran) Hustedt and Skeletonema costatum (Grev.) Cleve. J Exp Mar Biol Ecol 29:161-179

Nagata T (2000) Production mechanisms of dissolved organic matter. In: Kirchman DL (ed) Microbial ecology of the oceans. Wiley-Liss, New York, NY

Niklas KJ, Enquist BJ (2001) Invariant scaling relationships for interspecific plant biomass production rates and body size. Proc Natl Acad Sci USA 98:2922-2927

- Obernosterer I, Herndl GJ (1995) Phytoplankton extracellular release and bacterial-growth dependence on the inorganic N:P ratio. Mar Ecol Prog Ser 116:247-257

Orellana MV, Matrai PA, Leck C, Rauschenberg CD, Lee AM, Coz E (2011) Marine microgels as a source of cloud condensation nuclei in the high Arctic. Proc Natl Acad

Editorial responsibility: Graham Savidge,

Portaferry, UK
Sci USA 108:13612-13617

> Raven JA (1998) The twelfth Tansley Lecture. Small is beautiful: the picophytoplankton. Funct Ecol 12:503-513

Romera-Castillo C, Sarmento H, Álvarez-Salgado XA, Gasol JM, Marrasé C (2010) Production of chromophoric dissolved organic matter by marine phytoplankton. Limnol Oceanogr 55:446-454

Savage VM, Gillooly JF, Woodruff WH, West GB, Allen AP, Enquist BJ, Brown JH (2004) The predominance of quarter-power scaling in biology. Funct Ecol 18:257-282

Sun J, Liu D (2003) Geometric models for calculating cell biovolume and surface area for phytoplankton. J Plankton Res 25:1331-1346

Tang EPY, Peters RH (1995) The allometry of algal respiration. J Plankton Res 17:303-315

Teira E, Pazó MJ, Serret P, Fernández E (2001a) Dissolved organic carbon production by microbial populations in the Atlantic Ocean. Limnol Oceanogr 46:1370-1377

Teira E, Serret P, Fernández E (2001b) Phytoplankton sizestructure, particulate and dissolved organic carbon production and oxygen fluxes through microbial communities in the NW Iberian coastal transition zone. Mar Ecol Prog Ser 219:65-83

West GB, Brown JH, Enquist BJ (1997) A general model for the origin of allometric scaling laws in biology. Science 276:122-126

West GB, Brown JH, Enquist BJ (1999) The fourth dimension of life: fractal geometry and allometric scaling of organisms. Science 284:1677-1679

> Wolter K (1982) Bacterial incorporation of organic substances released by natural phytoplankton populations. Mar Ecol Prog Ser 7:287-295

Wood AM, Van Valen LM (1990) Paradox lost? On the release of energy rich compounds by phytoplankton. Mar Microb Food Webs 4:103-116

Zlotnik I, Dubinsky Z (1989) The effect of light and temperature on DOC excretion by phytoplankton. Limnol Oceanogr 34:831-839

Submitted: August 30, 2012; Accepted: November 14, 2012 Proofs received from author(s): February 22, 2013 